\title{
MAIN TRENDS OF DERIVATIVES' MARKET DEVELOPMENT IN CENTRAL AND EASTERN EUROPE
}

\author{
Kostiantyn VOZIANOV', \\ Kyiv National Economic University named after Vadym Hetman, Ukraine
}

\begin{abstract}
The aim of the study is to examine the factors of formation and development of the derivatives market in Central and Eastern Europe (CEE), to analyze the features of the organization and functioning of these markets, as well as to identify modern trends of development of the derivatives markets of CEE. The methodological basis of the study are historical and logical and systematic approach to the analysis of economic phenomena and processes in national and global environment. The study was conducted using the methods: qualitative and quantitative comparison, factor and structural analysis. Results. The development of the CEE derivatives market is characterized by: rapid growth of derivatives trading for the past two decades; high concentration of trading volumes on the stock market; offering a wide range of derivative products allowing investors to effectively hedge risk or get exposure; exchange consolidation; tendency to increased use of modern telecommunication technologies etc. The key problems of CEE derivatives market are low liquidity and international profile of exchanges and the lack of domestic investors for achieving the desired depth of the market. Practical implications. Research of the derivatives market makes it possible to understand more about the mechanism of functioning of the modern financial sector. In our opinion, special attention should be paid to CEE countries, where the development of the derivatives market began in the 1990s. To date, they are understudied, although they have considerable growth potential and in the future can compete on equal terms with Western European and American markets. Moreover, the starting conditions of development of the derivatives market in the CEE countries are more similar to the market of Ukraine and could be useful in terms of adapting good practices.
\end{abstract}

Key words: derivatives market, futures, options, stock exchanges in Central and Eastern Europe, exchange-traded derivatives, exchange consolidation, trading system.

JEL Classification: F30, F29, G100

\section{Introduction}

Derivatives markets have become an important part of the global market in general and the international monetary and financial relations in particular. With the participation of the derivatives market, the process of risk management has become more sophisticated, it will bring the world's monetary and financial relations to a higher level of development. World trade in derivative financial instruments provides the integration of regional capital markets and, consequently, helps participants of the world economy to reduce existing risks and to focus on further development of international trade and monetary relations. This reduces risk and balances international capital flows.

Traditional instruments of international investment, such as loans, bonds, stocks and foreign direct investment can be potential sources of foreign exchange, interest rate, market and credit risks for both lenders and borrowers. Derivatives make foreign investment attractive and thus contribute to the international movement of capital and create more opportunities for diversification of investments.
Globalization processes, which not only quantitatively but also qualitatively change the system of international economic relations, significantly influence the structure of the European stock market and its individual segments. Given the integration and investment priorities of economic development of Ukraine, studies of modern trends of development of the derivatives market in Central and Eastern Europe (CEE) are becoming increasingly important, since fixed-term contracts rank first among the various risk management tools in financial markets.

Research of the derivatives market makes it possible to understand more about the mechanism of functioning of the modern financial sector. In our opinion, special attention should be paid to CEE countries, where the development of the derivatives market began in the 1990s. To date, they are understudied, although they have considerable growth potential and in the future can compete on equal terms with Western European and American markets. Moreover, the starting conditions of development of the derivatives market in the CEE countries are more similar to the

\footnotetext{
Corresponding author

${ }^{1}$ Department of International Finance, Kyiv National Economic University named after Vadym Hetman.

E-mail: kostya8282@gmail.com
} 
domestic market and could be useful in terms of adapting good practices.

The aim of the study is to examine the underlying factors of formation and development of the derivatives market in Central and Eastern Europe, to conduct a comparative analysis of the characteristics of the organization and functioning of these markets, as well as to distinguish modern trends of development of the derivatives markets of CEE countries in terms of globalization.

\section{Features of CEE derivatives market functioning}

The Central and Eastern European region is rightly considered to be a rapidly developing one. The derivatives market in these countries started to develop due to several factors, which have equally contributed to its popularization in the recent past. Among these factors, the following should be highlighted: a focus on risk management; an increase in the range of small and institutional investors' awareness of derivative securities and all possible benefits associated with their use; thorough and effective legal framework (Schröder, Köke, 2003).

Exchange derivatives trading is popular in the CEE countries. The stock market, in contrast to the OTC, provides greater standardization of trade, better coherence of settlement mechanisms that reduce the degree of financial risk, and a developed interbourse system of electronic communication. Together with the developed markets of the world, stock exchanges in the show a tendency to increased use of modern telecommunication technologies.

Just 25 years ago, it was impossible to imagine a growing derivatives market in Central and Eastern Europe, because stock markets were mothballed. Upon return to the market economy, the countries of Central and Eastern Europe (Poland, Romania, Slovakia, Czech Republic) immediately began to implement structural reforms and therefore have made significant progress. This group of countries is characterized by rapid overcoming of the economic recession of 1992-1994 and gradual economic growth at a steady pace.

One of the fundamental factors of creation of the derivatives market in these countries was the government policy. Government policies in the countries of the Central and Eastern Europe after the emergence of derivatives markets have been well thought-out and coherent, carried out in several stages, addressing specific, clearly defined tasks within the overall strategy to promote the development of the market and in the context of the overall reform of the financial sector. A feature of the derivatives markets of CEE countries is that they have developed under constant supervision and control of the state, which used the experience of other countries.

Shortly after the resumption of the stock exchanges, derivatives have appeared. In Hungary, futures trading began on the Budapest Stock Exchange in 1996. The first instruments were futures on currencies and interest rates. Poland began derivatives trading on the Warsaw Stock Exchange (WSE) in 1998, launching futures on the WIG20, the calculation of which includes the 20 largest and most liquid companies (so-called blue chips) listed on the stock exchange. To date, these two exchanges continue to dominate in derivatives trading in CEE, while Warsaw remains the leader.

Many economists believe that the Warsaw Stock Exchange is the only market characterized by liquidity. In its region this market leads both in the development of the derivatives market, and in attracting a significant number of retail investors.

The Warsaw Stock Exchange is the only place in Central and Eastern Europe, which offers investors a wide and diversified range of derivatives. Starting with one product only in 1998 the WSE offers now a wide range of derivative products allowing investors to effectively hedge risk or get exposure. The offer includes index, single-stock, currency and interest rate futures, index options. WSE keeps broadening its offer in an effort to meet investors' needs (Warsaw Stock Exchange. (2012). Derivatives, Structured Products, ETFs Short Selling on the Warsaw Stock Exchange).

The rapid growth of derivatives trading for the past two decades proves the potential of the CEE region. Resistance of the ETD (exchange-traded derivatives) market amid the global economic downturn is also a confirmation of the potential of the region as a whole. However, if the derivatives market in CEE wants further dynamic development, it is necessary to work on the harmonization of the regulatory policy and new product development and innovation in the work of exchanges.

Despite the fact that all exchanges are regulated by the Markets in Financial Instruments Directive, and the European Union provides a framework regulation, the legal systems of each country are different from each other and each market develops its own set of rules and regulations.

The key problems of CEE exchanges are low liquidity and international profile. The only exception is the Polish market. Stock exchanges experience a lack of derivatives market instruments, so participants most often concentrate their operations on ordinary shares.

Another problem is the lack of domestic investors in order to achieve the desired depth of the market. This aspect repels large institutional investors.

\section{Exchange consolidation}

One of the trends that swept the region in the early 21 st century is a wave of mergers and acquisitions on the stock exchanges of the CEE region, the growing interest on the part of West European exchanges in the region, holding of a controlling stake of several exchanges in the region by one holding company.

Thus, the Vienna Stock Exchange began its expansion in the CEE market in 2004. Together with the Austrian banking consortium it acquired shares of the Budapest Stock Exchange, thereby laying the foundation of CEE Stock Exchange community. In June 2008, Wiener Börse 
AG (the company owning the Vienna Stock Exchange) acquired the shares of Ljubljana Stock Exchange, and shares of the Prague Stock Exchange were purchased in November.

Thus, the existing strong alliance of stock exchanges in Central and Eastern Europe was finally formed in 2008. It includes: Vienna (100\% stake), Budapest (50.45\% stake), Ljubljana (100\% stake) and Prague (92.74\% stake) stock exchanges. In September 2009, the brand «CEE Stock Exchange Group» (CEESEG, group of stock exchanges in Central and Eastern Europe) was officially launched. This policy strengthens the position of all four exchanges, takes them on a different level of development, and in the future will help occupy an internationally acceptable niche (CEE Stock Exchange Group. (2015). The holding company CEESEG AG)

Especially from a derivatives perspective, Wiener Börse's creation of the CEE Stock Exchange Group has gone a long way to consolidate the landscape in Eastern Europe. Of the four exchanges combined under the umbrella, all but Ljubljana offer derivatives.

Along with the acquisitions, Wiener Börse has been integrating the data feeds from Budapest, Ljubljana and Prague into its own data feed. In September 2009, Vienna launched the CEESEG Traded Index (CEETX) of the 25 most actively traded shares across its markets, and the CEESEG Composite Index, which includes all the stocks in each market's index (Futures \& Options World. (2010). CEE: rivals vie for the space between Frankfurt and Moscow (2010, November 30).

In January 2010, the four exchanges were transformed into subsidiaries of the holding company CEE Stock Exchange Group, which is dominated by Vienna. Also in 2010, the project of joint data dissemination of all CEESEG members thus has been fully completed. In September 2011, four CEESEG Sector Indices and three CEESEG Top Dividend Indices were launched.

In December 2013, The Budapest Stock Exchange launched the trading platform Xetra and thus became the fourth CEESEG member, alongside Ljubljana, Prague and Vienna, to be operating on this internationally recognized trading platform. Xetra is now the uniform trading platform for the CEE Stock Exchange Group. This marks another milestone in the harmonization of the Group's technical infrastructure.

The market capitalization of the Group, consisting of the four exchanges, reached 132.9 billion EUR in July 2015 . This is almost half of the total market capitalization in the CEE region. Vienna accounts for the largest share of the Group capitalization: about 87,7 billion EUR (CEE Stock Exchange Group (2015), Budapest - Ljubljana - Prague Vienna. Key Figures June 2015).

The primary objective of CEE Stock Exchange Group is to strengthen and provide domestic positioning of the capital markets at all CEESEG member exchanges. The medium- and long-term goal is to raise liquidity and to strengthen international profile of all stock exchanges of the Group.

\section{Derivatives market development in CEE (by exchanges)}

The history of the Budapest Stock Exchange' (BSE) derivatives segment began in 1996 with the trades in index futures and some foreign exchange futures. In 1998, there appeared futures on single stocks.

Soon, the BSE offered a full range of equity options and futures and currency futures. The most popular, accounting for about $30 \%$ of trading, is Bux Index Future. Another third comes in single stock futures, while $40 \%$ currency futures (Budapest Stock Exchange. (2015). Annual statistics 2014). The number of contracts on the BSE has grown from 0.07 million in 1996 to 11.8 million in 2011 (see Figure 1).

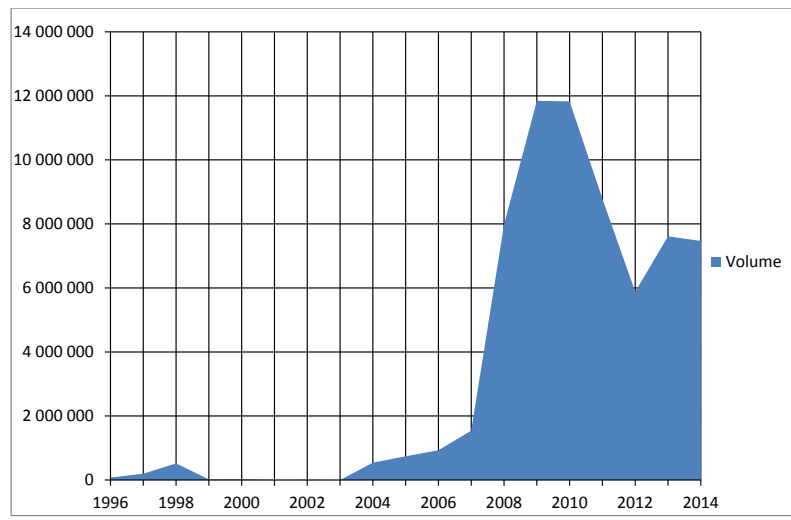

Source: Budapest Stock Exchange

Fig. 1. Budapest Stock Exchange Derivatives Annual Volume 1996-2014 (no. of contracts)

As defined previously, CEE stock markets have a common problem of activity of exclusively national retail investors in the market. Foreign investors are simply not interested in the market, so the capabilities of the derivatives market are rather limited. The depth of the market is not sufficient, so the activity is due to speculative operations of retail investors.

Management of the BSE hopes that the participation in the CEESEG will help it to achieve the scale economy, although it understands the tremendous inner work that should be done. Despite the current lack of liquidity, the BSE's ambition is to draw on its market not only members of Wiener Börse, but also the European investment community in general.

In December 2013, on the occasion of the exchange's new trading platform launch the stock exchange trading was ceremonially opened by Mr. Mihály Varga, Minister for National Economy. That day the new Xetra trading system replaced the system that has been in use for 15 years (MMTS, multi-market trade system). With the introduction of the new platform companies listed on the Hungarian exchange are linked to the traders and investors of 18 European countries while Hungarian investment providers and investors have direct access to thousands of new instruments, thereby the possibility of further market 
expansion opens up (Budapest Stock Exchange. (2015). Brief history of the Exchange).

The Prague Stock Exchange (PSE) introduced futures in September 2006. They include futures on single stocks and PX index, which includes 14 shares of the main market. Yet, it is worth noting that trade in derivatives on an exchange is not very active. In general, according to the exchange's management, the market is not used to the derivatives.

Trade in Prague is carried out by national institutions. The Prague Stock Exchange (PSE) wants to increase activity in the derivatives market through marketing and awareness-raising activities, but agrees that liquidity on the stock exchange is inadequate and domestic investors, who know about the tools of the derivatives market, are too conservative to use them in trading on the exchange. In background of insufficient liquidity the Prague Stock Exchange has no plans of any further product development in derivatives in the near future.

In terms of technological development, Since 1998, the PSE has used its own internal trading system, Spad. In November 2012, the Prague Stock Exchange successfully launched the new trading platform Xetra, joining other members of the CEE Stock Exchange Group running the same trading system. The introduction of the new trading platform will give members of the CEESEG access to the market and vice versa.

In connection with the change of the Prague Stock Exchange trading system to the Xetra, PSE in August 2012 has decided not to list any further futures, considering the fact that products listed in June 2012 would expire after the scheduled transition to Xetra, which does not support derivatives trading. All listed products (with maturities in June 2012 and September 2012) were expired according to their standard maturity dates. New products will be listed on the EUREX Vienna platform in line with the intention to consolidate CEESEG derivatives trading within a single market (Prague Stock Exchange. (2015). Termination of futures trading on PSE (August 06, 2012).

Management of the PSE notes that the key benefit of participation in the CEE Stock Exchange Group for members of their exchange and other member exchanges will be interrelation between all markets.

As of March 2014, the Vienna Stock Exchange (Wiener Börse AG) will no longer offer trading in derivatives. This decision was taken at meeting of the Supervisory Board of Wiener Börse AG in September, 2013. The Vienna Stock Exchange reached the decision to discontinue trading in derivative market products for economic reasons. Options and futures on Austrian stocks have been traded since 2006 on the Eurex Exchange - one of the world's largest markets for derivatives. The Austrian exchange will now focus on its equity and bonds markets going forward, along with continuing its services in index development. Wiener Börse calculates and publishes 89 indices with 66 related to CEE (Central and Eastern Europe) and CIS (Commonwealth of Independent States) markets (Futures \& Options World. (2014). Vienna Stock Exchange exits derivatives trading (March 24, 2014).
The Warsaw Stock Exchange (WSE) is a leading financial instruments exchange in Central and Eastern Europe (CEE) and one of the fastest growing exchanges in Europe. The markets operated by WSE list stocks and bonds of nearly a thousand local and international issuers. The Exchange also offers trade in derivatives and structured products, as well as information services. Close to 25 years of experience, high safety of trading, operational excellence and a broad range of products make WSE one of the most recognized Polish financial institutions in the world.

The capitalization of WSE at the end of 2014 was $15,1 \%$ bigger than the total capitalization of all CEESEG exchanges put together.WSE is the CEE leader by the number of listed companies (domestic and international). The Main Market listed 471 issuers and New Connect listed 431 issuers at the end of 2014. Post-trade services including depository, clearing and settlement services are offered by WSE's associate, the Central Securities Depository of Poland (KDPW), and its subsidiary KDPW_CCP (Warsaw Stock Exchange. (2015). About $G P W)$.

As of 15 April 2013, the Warsaw Stock Exchange operates a system (UTP) which meets top global standards, addresses growing expectations of market participants and ensures organization of trading in line with global trends. UTP developed by NYSE Technologies is well known to international investors and brokers on the world's biggest markets - this trading platform is used by the NYSE Euronext stock exchanges in New York, Paris, Lisbon, Amsterdam and Brussels, as well as many stock markets. Warsaw pulls plug on Vienna merger talks (September 24, 2014).

Compared to the legacy system, UTP is much faster, more efficient and scalable, and offers much enhanced performance: it can handle several dozen times more orders in the same time. With UTP, the Polish capital market opens up to new groups of investors including large global investment firms engaged in algorithmic trading. Algorithmic trading already accounts for 40 to 60 percent of all trade globally and its share is most likely to grow further. This presents an opportunity for growth and gives local Exchange Members a chance to increase their

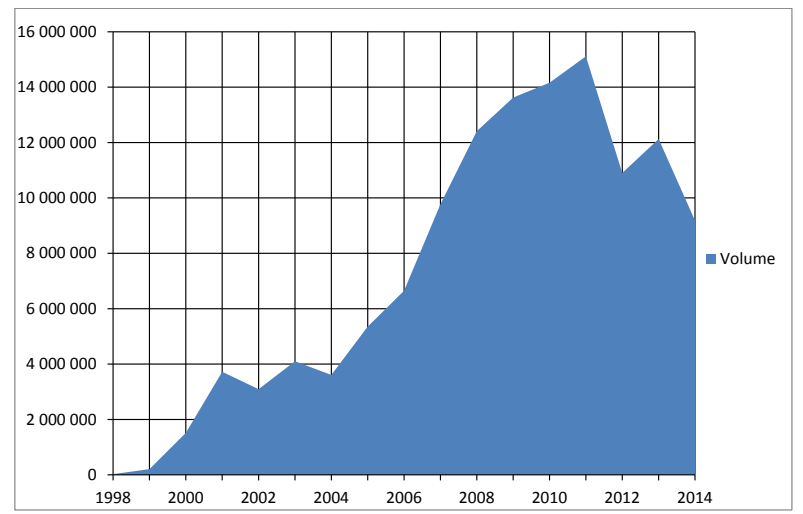

Source: Warsaw Stock Exchange

Fig. 2. Warsaw Stock Exchange Derivatives Annual Volume 1998-2014 (no. of contracts) 
revenues with the implementation of innovative solutions (Warsaw Stock Exchange. (2015). Utp - new trading system on the Warsaw Stock Exchange).

The Polish story has attracted substantial interest from abroad. Since January 1998, the derivatives market in Poland has shown an incredible leap in the development and is the most reliable and dynamic market in its region (see Figure 2).

The number of contracts on the WSE has grown from 0.02 million in 1998 to 15.1 million in 2011. CEE market investors show interest in the events on the Warsaw Stock Exchange (WSE). They constantly monitor the dynamics of derivatives based on the Polish stock index Wig Index and equity futures.

The strong points of the derivatives market in Poland, according to players, are large population, strong economy, domestic demand and financial community of the country. It is believed that Poland has reached a certain depth of the market and gained the necessary experience that enables further market growth.

Even the management of the stock exchange does not consider it a national one, because the very strategy of its development goes beyond the national boundaries. In matters of the market liquidity, Poland has succeeded in comparison with other CEE exchanges.

Regulatory environment in terms of derivatives in Poland is developing, but remains more conservative than its western neighbors. Although, if you look at the total turnover of the stock exchange and the total open position, Warsaw is head and shoulders above Austria, Hungary and the Czech Republic.

One of the problems faced by Poland, is that its regulatory framework largely prevents pension funds from derivatives trading. Despite recent progress of the WSE, net profit of the exchange decreased by $13.2 \%$ in the first quarter of 2012 compared to the same period last year. The fact that investment firms, asset management companies and pension funds are not involved in derivatives trading due to lack of proper legislative regulation, became a factor limiting the growth of the derivatives market as a whole.

However, the WSE's strategy covers not only national borders; it also beyond the CEE region. The management of the exchange states that the WSE sees Ukraine and Belarus as the two most important regions for itself. Given that these countries have inefficient capital markets, Warsaw wants to offer everything of interest for the region under one roof, i.e. at the WSE.

Future on the Wig 20 index is the stock index future that is sold most actively in Europe. The exchange offers the widest range of instruments of the derivatives market throughout the CEE region and it sees many benefits in combining several markets trading in stocks, bonds and derivatives, under one roof. Later, the exchange plans to cover the options market as well.

The WSE's strategy is aimed at attracting companies in CEE and their listing on its exchange, not on other stock exchanges in the region. Today, there are 23 foreign companies included in the list of the WSE's Main Market and 3 listed on the stock market New Connect, two of which from the Czech Republic and one from Bulgaria.

\section{Exchanges cooperation in CEE}

Thus, CEE Stock Exchange Group does not consider the Warsaw Stock Exchange as a competitor and shows its interest in cooperation with it.

Thus, the management of the Budapest Stock Exchange believes that the project of the CEE Stock Exchange Group is not a challenge to Warsaw, but rather an attempt to reach a higher level in terms of liquidity, risk level and international profile for all member exchanges. It is rather improvement and development of the markets of individual countries and the CEE region as a whole.

Economically, Poland is a very mature market, which will be increasingly reflected on its own derivative market. Hungary offers little real potential for growth by itself but as part of the CEESEG it could have an impact on how the markets in this region develop.

A merger or cooperation agreement between the Warsaw Stock Exchange and CEESEG could boost volumes and drive growth by making investment in the CEE region a more lucrative proposition.

In April 2013, the Warsaw Stock Exchange and CEE Stock Exchange Group were entered into preliminary discussions to explore a partnership. The merger with the Vienna stock exchange was a fundamental aspect of WSE's 2020 strategy.

But in September 2014 the Warsaw Stock Exchange has drawn a line under its proposed merger with Vienna's CEE Stock Exchange Group to form a regional powerhouse, saying the WSE management has opted instead to focus on "organic growth" (Futures \& Options World. (2014). Warsaw pulls plug on Vienna merger talks (September 24, 2014). A merger or cooperation agreement between the Warsaw Stock Exchange and CEESEG may be a perspective of derivatives market development in Central and Eastern Europe.

\section{Conclusions}

Globalization processes, which not only quantitatively but also qualitatively change the system of international economic relations, significantly influence the structure of the European stock market and its derivatives market.

The development of the CEE derivatives market is characterized by:

- high concentration of trading volumes on the stock market;

- developing under constant supervision and control of the state;

- rapid growth of derivatives trading for the past two decades (Budapest and Warsaw Stock Exchanges continue to dominate in derivatives trading in CEE, while Warsaw remains the leader); 
- conscious support of the demand for resources of the stock market through regulation of institutional investors' activities and creating conditions for participation of households in the market;

- provision of an appropriate legislative framework for the functioning of the market, which guarantees the protection of the rights of players;

- offering a wide range of derivative products allowing investors to effectively hedge risk or get exposure;

- tendency to increased use of modern telecommunication technologies.

The key problems of CEE derivatives market are low liquidity and international profile of exchanges and the lack of domestic investors (for achieving the desired depth of the market).
Especially from a derivatives perspective, Wiener Börse's creation of the CEE Stock Exchange Group (Vienna, Budapest, Ljubljana and Prague stock exchanges) has gone a long way to consolidate the landscape in Eastern Europe. The main aim of CEE Stock Exchange Group is to raise liquidity and to strengthen international profile of all stock exchanges of the Group.

CEE Stock Exchange Group does not consider the Warsaw Stock Exchange as a competitor and shows its interest in cooperation with it. A merger or cooperation agreement between the Warsaw Stock Exchange and CEESEG could boost volumes and drive growth by making investment in the CEE region a more lucrative proposition. It may be a perspective of derivatives market development in Central and Eastern Europe.

\section{References}

Budapest Stock Exchange. (2015). Annual statistics 2014. Retrieved from http://bse.hu/topmenu/trading_data/ stat_hist_download/periodical_statistics/stat_fig.html?pagenum $=15$

Budapest Stock Exchange. (2015). Brief history of the Exchange. Retrieved June 17, 2015 from http://bse.hu/ topmenu/about_us/history

CEE Stock Exchange Group (2015), Budapest - Ljubljana - Prague - Vienna. Key Figures June 2015. Retrieved from http://www.ceeseg.com/static/cms/sites/ceeseg/en/media/pdf/facts-figures.pdf

CEE Stock Exchange Group. (2015). The holding company CEESEG AG. Retrieved June 17, 2015 from http:// www.ceeseg.com/about/organization-structure/

Futures \& Options World. (2010). CEE: rivals vie for the space between Frankfurt and Moscow (2010, November 30). Retrieved from http://www.fow.com/2723404/CEE-rivals-vie-for-the-space-between-Frankfurt-and-Moscow. html.html?Keywords=Poland

Futures \& Options World. (2014). Vienna Stock Exchange exits derivatives trading (March 24, 2014). Retrieved from http://www.fow.com/3322644/Vienna-Stock-Exchange-exits-derivatives-trading.html. html? Keywords=Vienna+Stock+Exchange+exits+derivatives+trading+

Futures \& Options World. (2014). Warsaw pulls plug on Vienna merger talks (September 24, 2014). Retrieved from http://www.fow.com/3383505/Warsaw-pulls-plug-on-Vienna-merger-talks.html

Prague Stock Exchange. (2015). Termination of futures trading on PSE (August 06, 2012). Retrieved from https: // www.pse.cz/Novinky/Detail.aspx?ka=2696

Schröder, Michael and Jens Köke (2003), The Prospects of Capital Markets in Central and Eastern Europe, Eastern European Economics 41, No.4, 5-37.

Warsaw Stock Exchange. (2012). Derivatives, Structured Products, ETFs Short Selling on the Warsaw Stock Exchange. Retrieved from http:/9www.gpw.pl/pub/files/PDF/artykul/derivatives_structured_products_etf_2012.pdf

Warsaw Stock Exchange. (2015). About GPW. Retrieved August 10, $201 \overline{5}$ from http://www.gpw.pl/o_spolce_en

Warsaw Stock Exchange. (2015). Utp - new trading system on the Warsaw Stock Exchange. Retrieved August 10, 2015 from http://www.gpw.pl/trading_system_utp

\section{Константин ВОЗИАНОВ}

\section{ОСНОВНЫЕ ТЕНДЕНЦИИ ВОСТОЧНОЙ ЕВРОПЫ \\ РАЗВИТИЯ РЫНКА ДЕРИВАТИВОВ ЦЕНТРАЛЬНОЙ

Аннотация. Целью исследования является изучение факторов становления и развития рынка деривативов в странах Центральной и Восточной Европы (ЦВЕ), анализ особенностей организации и функционирования данных рынков, а также определение современных тенденций развития рынков производных ценных бумаг стран ЦВЕ. Методологической основой исследования являются историко-логический и системный подходы к анализу экономических явлений и процессов в национальной и глобальной среде. Исследование проведено с использованием методов: качественного и количественного сравнения, факторного и структурного анализа. Результаты показали, что развитие рынка деривативов ЦВЕ характеризуется: стремительным ростом торговли деривативами на протяжении последних двух десятилетий; высокой концентрацией объемов торгов на биржевом рынке; расширением числа инструментов, которые позволяют инвесторам эффективно хеджировать риски; консолидацией бирж; тенденцией к переходу 
Vol. 1, 2015

бирж на использование современных телекоммуникационных технологий и др. Ключевыми проблемами рынка деривативов ЦВЕ являются низкая ликвидность и международный профиль, а также недостаточное количество внутренних инвесторов для достижения необходимой глубины рынка. Практическое значение. Исследование рынка производных ценных бумаг дает возможность понять механизм функционирования современного финансового сектора. Особого внимания, на наш взгляд, заслуживают страны ЦВЕ, где развитие рынка деривативов началось в 90-х годах прошлого века. На сегодняшний день они остаются недостаточно изученными, хотя имеют значительный потенциал роста и в будущем могут конкурировать на равных с западноевропейскими и американским рынками. Более того, условия, в которых начиналось развитие рынка деривативов в странах ЦВЕ, являются несколько схожими с рынком Украины и могут быть полезными с точки зрения адаптации положительного опыта. 